\title{
I LO: Social Justice in a Global World? A History in Tension
}

\author{
Sandrine Kott
}

\begin{abstract}
This contribution analyses, from a historical perspective, the ways in which the International Labour Organization has been able to affirm and fulfil the mission entrusted to it in 1919: to represent the worlds of labour and promote social justice in a universal way. It shows that, from its inception, the Organization has been locked in a fundamental contradiction between the promise of social justice and the decommodification of labour that this promise expresses, on the one hand, and the Organization's role as a social agent of economic globalisation, on the other. This tension increased after the Second World War, in the context of the Cold War and decolonisation.
\end{abstract}

\section{Introduction}

The International Labour Organization (ILO) was founded in 1919, as a corollary of the peace treaties that marked the end of the First World War. Its Constitution forms Part XIII of the Treaty of Versailles. Until 1940, it functioned as a sort of technical agency for the League of Nations (Tortora, 1980). But unlike the League, it survived World War II, moving to Montreal in 1941. It was reborn in 1944, when the principles presiding over its foundation were reaffirmed in the text of the Declaration of Philadelphia in the Appendix to its Constitution. In 1946, it officially became a specialised agency of the United Nations (Alcock, 1971; Ghebali, 1989).

The ILO celebrates its centenary in 2019, which it decided to dedicate to the 'future of labour' (ILO, 2018a). This decision calls for some remarks. While prophesying the 'end of labour', the Organization has chosen to reaffirm the importance of labour for the world's future but it has apparently given up thinking about its own future. It seems reluctant to re-examine its past and to use history as a tool for thinking about that future, although its history is rich in lessons. 
A great deal of historical work has been done on the ILO (Van Daele, 2008) and, in the last ten years, this corpus has grown, and opened up new avenues for reflection. With the global turn taken by the social sciences, the Organization has become a popular field for such expanding areas of study as the history of human rights, economic development, networks, and social reform; this research testifies to the centrality of the Organization and labour-related issues when it comes to thinking about the world (Van Daele et al., 2010; Lespinet-Moret and Vincent, 2011; Aglan et al., 2011; Kott and Droux, 2013). In addition, the history of labour, neglected since the 1980 s, has recently seen a renewed surge of interest. In the 1960s and 1970s, this field of study was mainly focused on the history of workers and the affirmation of workers' culture, giving rise to studies of the practices and forms of collective expression, carried out using a 'bottom-up' approach and paying close attention to particular territories. As evidenced by debates on the issue of free or coerced labour and informality (Brass and Van der Linden, 1997), current research is taking labour out of the industrial workshop and looking more clearly at the diversity of its forms. Last but not least, historians have opened up their geographic space of investigation: labour is now grasped in its global and transnational dimension, and the proponents of this approach are showing an increasing interest in connections between workers and their circulation. Labour historians use the archives and documents produced by the ILO, but they also share the current concerns of the Organization when it reaffirms the importance of labour and workers in our global economy (Louis, 2011). This perspective lies behind the actual creation of the Organization, and behind the measures implemented to accomplish its mission and the tensions and limits on its actions (International Labour Office, 1931, 15-16).

This contribution therefore analyses, from a historical perspective, the ways in which the International Labour Organization has been able to affirm and fulfil the mission entrusted to it in 1919: to represent the worlds of labour and to promote social justice in a universal way. To this end, I will first explore the genesis and founding texts of the Organization to understand how it conceived and organised its mission of social justice (Gerry et al., 2009). Then, starting from the formula with which the Declaration of Philadelphia begins'labour is not a commodity' - I will examine the tensions created within the Organization by the contradiction between the social objectives that it is supposed to promote and the conditions for their realisation in an open capitalist economy. Finally, I will explore the solutions implemented by the ILO during its first fifty years of existence to work towards a fair globalisation for workers. 


\section{Social Justice at the Heart of the ILo's Mission}

The founding principles of the ILO were formulated in 1919 and have remained the same. The Constitution of the Organization has barely changed and begins with this premise: 'Universal and lasting peace can be established only if it is based upon social justice', which gives the ILo essentially three filiations. The promise of social justice was first and foremost a response to the demands of the reformist workers' movement that came together in the union sacrée during the First World War. At the international trade union conference in Leeds, Great Britain, in 1916, trade union representatives of the nations that were allied against Germany called for the creation of an international labour organisation, a kind of world parliament in which the social demands of the labour movement would be discussed and examined (ILC, 1916; Riegelman, 1934; Tosstorff, 2005). Social Christianity was another inspiration as well as a cornerstone for the foundation of the ILO. Since the publication of the encyclical Rerum novarum in 1891, the social doctrine of the Catholic Church had clearly been based on a demand for justice, taken up and amplified by the Catholic and Christian workers' movement (Pasture and Govaert, 1999). But the ILO was also the direct heir to liberal social reform, some of whose movements had already organised themselves within various international associations. The ILO inherited the library, staff and part of the social programme of the most highly organised of these bodies, the International Association for Labour Legislation, based in Basel since 1901 (Kott, 2014; Van Daele, 2005). These networks played a vital role in the birth of the International Labour Office (the Secretariat of the Organization) and in its survival during the first twenty years of its existence. Its first director, French socialist Albert Thomas, was also keen to ensure their cooperation by developing and organising their support to the Organization (International Labour Office, 1931, 424-468). The proponents of the different movements agreed on two points: capitalist industrialisation had generated mass poverty that might lead to political and social unrest; and this social question could and should be tackled by social reforms within the existing political and economic order. In 1919, this reform activity developed along three main lines: protection, redistribution and collective bargaining. Nevertheless, areas of contention still existed within the movement, especially concerning the role that should be attributed to the different stakeholders. Socialists emphasised the regulatory role of the state; the Christian movement, joined by the cooperative tradition, was more favourable to the development of free associations based on the self-help mode; and employers insisted on the importance of free enterprises that could generate economic growth to finance social spending. 
The idea of social justice itself has never been the subject of theoretical debate within the ILO. However, the preamble and general principles of the 1919 Constitution, and then in the Declaration of Philadelphia that replaced it in 1944, defined a number of objectives that constitute the foundations of the Organization:

Regulation of the hours of work including the establishment of a maximum working day and week; Regulation of labour supply, prevention of unemployment and provision of an adequate living wage; Protection of the worker against sickness, disease and injury arising out of his employment; Protection of children, young persons and women; Provision for old age and injury, protection of the interests of workers when employed in countries other than their own; Recognition of the principle of equal remuneration for work of equal value; Recognition of the principle of freedom of association; Organization of vocational and technical education and other measures. ${ }^{1}$

The ILO's normative activities thus originally aimed to achieve these different objectives (Bonvin, 1998) in the form of a sort of international labour code, inspired by the legislation implemented in the most socially advanced nations. The main task of the Committee on International Labour Legislation, meeting in Paris between January and April 1919, was to define the modalities for the creation of such a code. The Italian and French representatives proposed that the International Labour Conference - the parliament of the future Organization - be able to adopt conventions that would be automatically binding on the member states; the British, for their part, favoured an almost automatic ratification system. However, under pressure from US negotiators, the power of the Organization was reduced to such an extent that it became almost entirely dependent on national stakeholders (Shotwell, 1934). Until today, the ILO's recommendations are only indicative and the conventions must be ratified by the national parliaments of the member states. In general, however, states have no interest in ratifying a convention: not only does ratification involve bringing the country's legislation into line with ILO rules, it also constitutes a heavy commitment subordinated to an annual supervisory system, constraints that states have been trying to escape (Maupain, 2010). This tension, already present at the time of the adoption of the very first ILO convention - the convention on the eight-hour day—partly explains why the

1 See the website http://www.ilo.org/global/about-the-ilo/history/lang--en/index.htm (accessed on 17 July 2018). 
ILO's normative system has always been developed under strained conditions. This first convention was symbolic, since the eight-hour day lay at the heart of the demands of the worldwide workers' movement but it was not ratified by any of the major industrial countries despite the efforts of Albert Thomas. In reality, the activities of the ILO and the adoption of its conventions have always been very dependent on the commitment of governments and the various national participants.

Despite these obstacles, the ILO carried out a considerable amount of normative work during the period between the First and Second World Wars. In all, 67 of the 189 conventions in force to date were adopted between 1919 and 1939, which means that more than a third of the conventions of this centuryold Organization were adopted during its first twenty years of existence (ILO, $2018 \mathrm{~b}$ ). This normative work, based on a skilful exchange of ideas between ILO officials and those of national administrations, enabled the establishment of a recognised social expertise and know-how disseminated by ILO officials, of whom there were no more than 400 in 1931 (Kott, 2008).

In 1919, the three main social reformist schools of thought agreed on various social goals in the specific context of the end of the war but their union was also aimed at countering the Bolshevik Revolution and the upsurge of European revolutionary movements (Phelan, 1949). The ILO, clearly founded as an 'alternative to violent revolution' (Shotwell, 1933, 18-25), was in return denounced by the communists, who accused it of betraying the fundamental interests of the working class under the guise of reforming capitalism. Until 1934, the Soviet Union refused to join the Organization.

Nevertheless, the Union of Soviet Socialist Republics (USSR) and the revolution were 'useful enemies' that the reformers could use to advance their social agenda. On his travels, Albert Thomas tirelessly stressed the importance of fighting against poverty in order to prevent revolution. This same argumentor belief-was used to prompt (or encourage) the funding of the major postSecond World War development programmes whose instigators, often former New Deal officials, joined the UN system through the United Nations Relief and Rehabilitation Administration (Ekbladh, 2010).

In 1919, the ILO embarked on a mission to convince the workers' movement that reformism was the solution that would ensure the well-being of all. To this end, it worked to disseminate information on the reality of the working-class situation in the USSR. From the beginning of 1920, at their second meeting, the members of the ILO's Governing Body raised the possibility of conducting an inquiry into the situation in Soviet Russia (ILO, 1920), for the stated purpose of disarming the upsurge of revolution by putting an end to the 'illusions' of the workers (ABIT, 1921). A Russian section was formed and, during the interwar 
period, the ILO became a kind of intelligence agency with regard to communism in the USSR. These thoroughly anti-communist activities were reactivated at the beginning of the Cold War. In the absence of the USSR, the leading American union, the American Federation of Labour, used the ILO to campaign against forced labour in the USSR and the countries that would form the Eastern Bloc (Kott, 2012). After the USSR re-joined the Organization in $1954,{ }^{2}$ the ILO became a platform for the two blocs to collaborate on the basis of a strong common belief in the need for more economic growth and increased productivity; this lasted until the crisis of 1977 and subsequent withdrawal of the United States from the ILO until 1980.

In addition to the direct struggle against the communist model, the ILO relied, from its inception, on its tripartite structure and the principles of collective negotiation meant to implement the reformist solutions that the Organization advocated. Tripartism is a cornerstone of the Organization and its representatives (governments, workers and employers) meet at the Annual Labour Conference and, four times a year, under the framework of the Administrative Council—or executive body—of the Organization. In the 199os, tripartism even entered the International Labour Office with the creation of offices of the Bureau for Workers' Activities (ACTRAV) and the Bureau for Employers' Activities (ACTEMP). Tripartism is consistent with a liberal reformist vision that seeks to correct the asymmetric power relations between workers and employers intrinsic to the employment contract through the organisation of collective bargaining. Tripartism stands in contradiction with the logic of state socialism, which does not distinguish between state and economic stakeholders. On the other side, the tripartite structure and the collective bargaining promoted by the ILO relied on the existence of organised social partners, and thus on freedom of association. This freedom of association, stated in the preamble to the 1919 Constitution, is therefore essential to the very functioning of the ILO. The 1948 Convention on Freedom of Association and Protection of the Right to Organise is a foundational Fundamental Convention of the ILO and, since 1951, its enforcement has been under a specific supervisory committee - the Committee on Freedom of Association. In the liberal social logic of the ILO, the presence of a representative union within companies is a guarantee of justice. It helps to tilt the balance of power in favour of the workers and ensure that their social situation is not systematically indexed to the economic results achieved by the company. With this in mind, the ILO could say that 'labour is not a commodity'.

2 The USSR initially joined the ILO in 1934 and left in 1940. 
US trade unionists were behind the first reference to the decommodification of labour as enshrined in the general principles of the ILO Constitution, adopted in 1919:

But, holding as they do that labour should not be regarded merely as an article of commerce, they think that there are methods and principles for regulating labour conditions which all industrial communities should endeavour to apply, so far as their special circumstances will permit. ${ }^{3}$

The encyclical Rerum Novarum already contained an explicit condemnation of labour as a commodity, but the wording chosen by the ILO was inspired by the Clayton Antitrust Act of 1914- That the labor of a human being is not a commodity or article of commerce' - which guaranteed, on this basis, the right to coalition and strike. Samuel Gompers, President of the American Federation of Labor (AFL), regarded this article as the Magna Carta of the workers and regretted that the term 'merely' had been added in the ILO text. It was again under the influence of the United States that the Declaration of Philadelphia, added as an annex to the ILO Constitution after the Second World War, confirmed and hardened this condemnation of labour as a commodity, stating that 'labour is not a commodity'.

The ILO tackled the issue of labour as a commodity as early as 1920, in the context of its normative work on fixing a minimum wage-one of the general principles expressed in its Constitution. The government delegate from Paraguay stated in 1920:

the delegation from Paraguay intends that incorporation of the American principle that human labour shall not be considered as merchandise shall include the principle, not only of limiting the working day, but also of the minimum wage in the various industries (LN, 1920, 130).

In 1944, the government delegate from Colombia went further by saying: 'Work should not be a commodity. There should be guaranteed living wages' (ILC, 1944, 101). This question of the minimum wage defined as a condition and an instrument of the decommodification of labour runs through the history of the Organization. The first Minimum Wage Fixing Convention was adopted

3 See Treaty of Versailles of 28 June 1919, Part XIII, Annex, Section II, Article 427 on the website http://avalon.law.yale.edu/imt/partxiii.asp (accessed on 17 July 2018). 
in 1928 after extensive research by the International Labour Office and was supplemented in 1970 by another convention that encouraged states to establish a minimum wage system (Reynaud, 2017). In general, the normative activity of the ILO has always been built on the idea that the conventional system, by placing workers under the protection of a political authority, constitutes a powerful tool for the decommodification of labour.

In practice, however, the Organization was soon faced with the limitations of its call for the the decommodification of labour as referred to in 1944 by the Indian workers' delegate:

The proclamation of this preamble of our Constitution and of Article 41 that workers are not a commodity is a paper declaration. Workers are a commodity in my country. I am afraid they are a commodity in many other countries (ILC, 1944, 81).

From the outset, the communists voiced a more fundamental criticism of the ILO, stating that it contributed to the perpetuation and even the propagation of labour as a commodity by agreeing to improve the capitalist rules of the game. This criticism was recently taken up by Guy Standing — an official in the ILO from 1975 to 2006-but from another point of view:

Depicted as reducing the commodity character of labour, the conventions actually helped to legitimise and spread 'fictitious decommodification': they made the activity of labour less like a commodity but fostered national systems in which workers' entitlements were increasingly dependent on the performance of labour and being in stable wage labour. If decommodification is about making people less dependent on the labour market, then making them more dependent on being in wage labour for their 'social rights' is a strange way of going about it (Standing, 2008, 355-384).

Guy Standing's statement must be understood in the light of his commitment to universal basic income, which is supposed to guarantee the subsistence of individuals regardless of their activity, or even the wages earned for their work. For its supporters, universal income is a modern and radical way of moving towards the decommodification of work.

However, from 1919 onward, the ILO has taken the opposite path, since its target group is composed of industrial wage earners- that is to say, workers employed in the 'labour market'. Although the self-employed have been formally covered by the Declaration of Philadelphia since 1944, workers holding a 
so-called 'standard' job - that is to say, wage-earners with an employment contract and protected by social legislation—still remain the main target group of ILO norms.

Many workers are thus excluded from the scope of the Organization; this is particularly the case for informal workers who, in India, make up almost 93 per cent of the labour force. Reproductive work, generally undertaken by women, should be added to informal labour. To overcome this difficulty, the ILO has largely promoted the development of wage labour and the generalisation of 'standard employment' conditions (meaning under contract). The 1930 Abolition of Forced Labour Convention (C 29) is a perfect illustration of this orientation; it aimed to transform forced labour into contractual wage work framed by the two 1939 agreements on employment contracts and penal sanctions, respectively (C 64 and 65) (Maul, 2012; Rodríguez-Piñero, 2005; Zimmermann, 2010; Daughton, 2013). While the ILO has promoted measures to frame and regulate labour as a commodity, the very principles on which it is based condemn it to accept its existence.

Under the mandate of David Morse, Director General from 1948 to 1970, the terms of the relationship were even reversed in favour of an economist's vision of labour as Morse, who previously worked in the New Deal administration, made increased productivity a central goal of organisational policy (Maul, 2010).

The ILO took an interest in the question of the scientific organisation of labour and elaborated a 'productivity policy' (Maier, 1977; Maier, 2010) as early as in the 1920s. This orientation led, for example, to the creation in Geneva in 1927 of the International Management Institute, headed by the Briton Lyndall Urwick. The Fordist model of welfare capitalism was the main inspiration behind all these productivist measures: by creating wealth, the increase in productivity was supposed to increase the purchasing power of the workers. This policy, which made social progress dependent on the results of the capitalist economy, soon met resistance from some employers, who refused to increase wages, as well as from unions, which feared a rise in unemployment (Cayet, 2010).

Nevertheless, from 1950, productivity became a priority of the Organization. In his 1950 report, David Morse asserted that 'From the world point of view the real need in almost every sector is for increased production' (ILC, 1950, 3). According to him, workers relied excessively on redistributive measures to increase their standard of living, whereas they needed to become responsible for their well-being by increasing their productivity at work.

Within the ILO, this ideological shift mainly expressed itself in two ways: the nature of the conventions evolved and the Organization redoubled its efforts 
to provide technical assistance. The conventions of the Cold War years were primarily intended to protect 'human rights' and to ensure fairness (including through the Convention on Discrimination) rather than to create the conditions necessary for greater equality. They aimed to 'empower' rather than protect workers (as in the conventions on freedom of association and collective bargaining of 1948). Furthermore, the ILO continued to carry out important normative work, but activities to encourage economic development took precedence over other areas as shown by the rising number of economists among the staff and the recruitment of many development economists as external experts.

As part of this policy in favour of economic development, the ILO set up and implemented productivity missions, the first of which was sent to Israel in 1952, one year before the activities of the European Productivity Agency (EPA) began - an agency placed under the authority of the European Organization for Economic Co-operation as part of the Marshall Plan. The EPA was created with the aim of increasing productivity in member countries and thus fighting poverty and preventing a revolution from breaking out (Boel, 2003). The ILO's productivity missions were the global component of the EPA's activities in Western Europe. After Israel, other missions were sent to India, Egypt, Pakistan, Yugoslavia, Brazil, Bolivia, Greece, Hong Kong and Ceylon (ABIT, 1952-56). At the request of many governments, the ILO set up productivity centres in which experts provided training (ILO, 1957a, 1957b). These productivity missions were systematically flanked by a management training programme for those in charge of labour organisation (ILO, 1965).

The productivist approach chosen by the ILO clearly established the primacy of the economic sphere over the social, but the Organization simultaneously reaffirmed its social goals within this economic framework. David Morse reminded the United Nations Economic and Social Council (ECOSOC) that productivity gains were intended to raise the standard of living of workers and to create jobs, that social benefits should flow from the economic results of employees, and that any measure to increase productivity should be negotiated between workers, trade unions and employers (ECOSOC, 1953; ILO, 1953). In 1950, in his speech to the International Labour Conference, he underlined the exemplary role played by the Czechoslovak trade unions which were able to negotiate the way increase of productivity should be organised with the directors of the state-owned enterprises, even though these trade unions fell under Convention 87 on freedom of association.

Thus the productivist turn of the 1950s stood in conflict with the values on which the Organization was based in two ways: it ran against the idea that the social sphere had to prevail over the economic, and it questioned the liberal 
conception of trade unions on which it was grounded. This productivist turn admittedly marked an inflection, but it endorsed the ILO's lasting assumption that economic prosperity was the condition of universal social justice.

\section{4}

\section{Fair Globalisation}

The third clause in the preamble to the ILo Constitution ${ }^{4}$ justifies the existence of the Organization with an economic argument:

Whereas also the failure of any nation to adopt humane conditions of labour is an obstacle in the way of other nations which desire to improve the conditions in their own countries.

At the time of its creation, the Organization was well placed to fight for social justice, but in a context of free trade and global economic competition. The idea that employers, forced by stricter national laws to offer better social protection to their employees, would be disadvantaged on the world market is an old belief that is not necessarily based on reliable calculations (International Labour Office, 1931, 15). However, like the revolutionary threat, it encouraged reforming employers to promote international social protection. The ILO has always situated itself in the tradition of the great free-trade reformers of the first half of the nineteenth century, such as Robert Owen and Daniel Legrand (International Labour Office, 1931, 4-5) and has seen, in the set up of international social norms, the very condition of undistorted economic competition. In 1944, Karl Polanyi summed up this point of view in the following terms:

The League of Nations itself had been supplemented by the International Labour Office partly in order to equalize conditions of competition among the nations so that trade might be liberated without danger to standards of living (Polanyi, 1944, 27-28).

From its inception, the ILO emerged as a social regulator of economic globalisation (Feiertag, 2008) that was at that time limited to the capitalist countries of the North Atlantic. Like the League of Nations on which it depended, it was initially a European enterprise (Guérin, 1996). At the 1930 International

4 The ILO Constitution is available on the website http://www.ilo.ch/dyn/normlex/en/ $\mathrm{f}$ ?p=1000:62:0::NO:62:P62_LIST_ENTRIE_ID:2453907:NO (accessed on 4 December 2018). 
Labour Conference, half of the 51 countries gathered were not European; but European states, especially the victors of the First World War, dominated the ILO: all the section chiefs were then French or British. In addition, a number of US participants played a major role at the time of the creation of the Organization. This includes members of the social reformist movement embodied by the American Association for Labor Legislation (the US branch of the International Association for Labour Legislation) — of which President Woodrow Wilson was an active member-and Samuel Gompers, President of the American Federation of Labor, who chaired the International Labour Commission that met in Paris from January to April 1919 and played a significant part in the discussions surrounding the birth of the Organization (Moynihan, 1960). In addition, the United States joined the ILO in 1934 despite never having been a member of the League of Nations.

The norms developed during this period were heavily inspired by the legislation in place in the economically developed world at the time, while colonies were subjected to special exemptions. As a result, the European and Latin American peripheries felt marginalised and threatened to create a rival organisation more suited to their needs. Asian countries, for their part, stated that their level of development did not allow them to implement a policy designed for developed countries. As early as the 1930s, ILO officials became aware of the need to 'help' economically and socially less developed countries in order to establish social legislation compatible with ILO norms and to offer their technical assistance for this purpose, first in the Balkans and subsequently in Latin American countries (Stenger, 2016; Kott, 2010). This technical support allowed the Organization to disseminate its model of social insurance by ensuring that the legislation put in place in these countries was compatible with its conventions.

During David Morse's term of office, the number of members of the Organization grew from $5^{2}$ to 121 as a consequence of decolonisation (meanwhile the number of staff increased fivefold). The question of the universality of norms thus came to the fore, and the ILO had to face new difficulties, in particular during the debates on the Convention on Social Security from 1950 to $195^{2}$. Representatives of the less developed countries stated that, given the embryonic state of their legislation, it was impossible for them to adopt European norms. Convention 102 proposed an à la carte solution allowing the least developed countries to select the branches of social security they wished to include first in their systems. Employers from northern countries were very hostile to this solution, which in their view distorted economic competition (Guinand, 2003). 
On the other hand, the ILO proceeded differently for the territories now described as 'non-metropolitan': in 1947, it adopted Conventions 83 to 86, which extended to the populations concerned the social rights in force in metropolitan areas. In 1950, a committee of experts on the social policies relating to the colonies (Committee of Experts on Social Policy in Non-Metropolitan Territories) was created to develop a funding strategy for these social policies (Cooper, 1996). At the same time, this question was discussed at the third InterAfrican Labour Conference - set up by the colonial administrators-whose main conclusions were taken up in 1953 by the ILO Committee. Insofar as it seemed certain that metropolitan participants could not invest as much as was needed in the colonies, the ILO proposed extending the European model of productivity to non-metropolitan territories by bringing African workers into the labour market, but also by training managers and workers and by developing a management culture. Finally, to encourage workers to be more productive, the Committee recommended the introduction of piecework (ILO, 1953). The extension of social policies was therefore, in this case too, closely linked to the economic results of the territories.

Similar policies for the countries of the global South were elaborated in the field of technical assistance and development, two objectives that became central for the ILO from 1949 (Alcock, 1971, 209-251, 338-364) and were implemented under the UN's Comprehensive Technical Assistance Programmelaunched by Truman (Point IV initiative) - in 1949, and later in the United Nations Development Programme from 1965 onwards. Within this UN development framework the ILO was primarily responsible for human resources, such as management training programmes aimed at increasing labour productivity. More than 2,00o experts, mostly economists, were recruited from outside the Organization and were sent to different countries between $195^{\circ}$ and 1959. The Organization also implemented a fellowship programme and then a programme of courses for supervisory staff from developing countries in the Turin International Training Centre, established in 1965. The common goal of the Organization and local political elites was to foster economic development to enable the various countries involved in these programmes to find their place in global economic competition. Once again, social progress was seen as the desirable outcome of increased economic performance, not as a prerequisite.

The ILO was certainly not responsible for this focus on economic development as a condition for human development; this approach espoused the logic that was then predominant, including in developing countries themselves. Similarly, in 1969, the Organization borrowed from India the 'basic needs' approach, which underpinned the World Employment Programme, set up in 
1969, and was then criticised for its excessive focus on production and consumption at the expense of the human factor. This contradiction between the social objectives of the ILO, and in particular its emphasis on decommodification of labour and its actions on the ground, had considerable consequences and undoubtedly accounted for much of the lack of interest accorded to it by developing countries at different times in its history. Thus, in 1995, when the ILO wished to negotiate the introduction of a social clause in the founding treaty of the World Trade Organization, the representatives of Indian trade unions opposed it on the pretext that removing a comparative advantage from their country with regard to international competition would throw millions of Indian workers out of work (Hensman, 2011).

\section{5}

\section{Conclusion}

From its inception, the ILo has been gripped by a fundamental tension, on the one hand between the promise of social justice and the decommodification of labour that this promise embodies, and its role as a social agent of economic globalisation on the other. This tension intensified in the years after the Second World War, in the context of the Cold War and decolonisation during which time the number of member states increased significantly, while the problems and the solutions to be implemented became increasingly divergent.

But the tensions that have run through the Organization also reflected the diversity of its sources of inspiration. Different movements have coexisted within the ILO right from the start: a liberal reformist wing, a social democratic tendency and a Christian social component. In addition, since the 1930s, the dominant normative approach pursued by jurists was accompanied by a developmentalist vision defended by an increasing number of economists, with the latter eventually coming to rival the former.

Despite their ambiguity and difficulty, the norms remain nevertheless important reference points even when they are not ratified. For their part, development policies have always subordinated social progress to economic performance and emphasised the notions of growth, productivity and consumption-even those that have been supported by progressive schools of thought, such as the World Employment Programme.

Last but not least, the ILO has always worked within a constrained space: constrained by national governments, constrained by the diverging interests of workers and employers, and constrained by the international system itself, in which the place occupied by the Organization has always been contested. During the period between the two world wars, the ILO had great difficulty finding 
its place in the economic negotiations, conducted under the auspices of the League of Nations, and to which ILO officials wished to add a social dimension. In addition, the Health Section of the League of Nations competed with certain sectors of the Organization's activities, relying on Rockefeller Foundation money, which was less accessible to the ILO. In the 1970s, the United Nations Industrial Development Organization (UNIDO) took over a large share of the ILO's development activities in industrialised countries, and the United Nations Educational, Scientific and Cultural Organization (UNESCO) took over a number of its training capacities.

Nevertheless, as long as communist regimes existed, the reformist stakeholders of the ILO mobilised and used the fear that these regimes aroused to advance their social agenda. Since the disappearance of this useful enemy, the ILO discourse of social regulation and normative practice has become more difficult to get across, especially in comparison with the Organisation for Economic Co-operation and Development (OECD) and the World Bank, both of which have advocated for liberal deregulation since the 1980's. Yet in a world where multinationals manage to free themselves from all national social legislation and where workers' mobility is increasing, the international norms proposed by the ILO should be on the agenda more than ever.

In this respect, the last Convention on Domestic Workers (C189, 2011) is both an opening and a model. It targets a group largely composed of women and migrants, a group doubly marginalised on the national level and much more dependent than others on international protection. The way in which groups of activists in different countries have seized on this subject, and on the rules laid down in the Convention, shows not just the symbolic but also the practical importance of such regulations and opens up new perspectives (Boris and Fish, 2014).

\section{References}

ABIT (Archives of the BIT [Bureau International du Travail/International Labour Of-

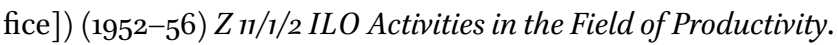

ABIT (1921) 502899 ILO Systematic Questionnaire and Bibliography on Labour Conditions in Soviet Russia, 1921.

Aglan, A., O. Feiertag and D. Kévonian (2011) Humaniser le travail: régimes économiques, régimes politiques et Organisation internationale du travail, 1929-1969 (Brussels: P.I.E. Peter Lang).

Alcock, A. (1971) History of the International Labour Organization (New York, NY: Octagon Books). 
Boel, B. (2003) The European Productivity Agency and Transatlantic Relations, 1953-1961 (Copenhagen: Museum Tusculanum Press/University of Copenhagen).

Bonvin, J.-M. (1998) L'Organisation international du Travail, Etude sur une agence productrice de normes (Paris: PUF), pp. 177-201.

Boris, E. and J.N. Fish (2014) "Slaves No More": Making Global Labour Standards for Domestic Workers', Feminist Studies, 40(2), pp. 411-443, https://www.jstor.org/ stable/10.15767/feministstudies.40.2.411.

Brass, T. and M. Van der Linden (eds.) (1997) Free and Unfree Labour: The Debate Continues (New York: Peter Lang).

Cayet, T. (2010) Rationaliser le travail, organiser la production: le bureau international du travail et la modernisation économique durant l'entre-deux-guerres (Rennes: Presses Universitaires de Rennes).

Cooper, F. (1996) Decolonization and African society: The Labour Question in French and British Africa (Cambridge: Cambridge University Press), pp. 218-224 and $362-369$.

Daughton, J.P. (2013) 'ILO Expertise and Colonial Violence in the Interwar Years', in S. Kott, and J. Droux (eds.) Globalizing Social Rights: The ILO and Beyond (London: Palgrave), pp. $85^{-98}$.

ECOSOC (United Nations Economic and Social Council) (1953) Working Paper prepared by the International Labour Office on the Role of Labour in Programmes for increasing Productivity, and Measures needed to safeguard the Interests of Workers, 16th Session, UN doc. E/2440.

Ekbladh, D. (2010) The Great American Mission: Modernization and the Construction of an American World Order (Princeton, NJ: Princeton University Press).

Feiertag, O. (2008) 'Réguler la mondialisation: Albert Thomas, les débuts du BIT et la crise économique mondiale de 1920-1923', Les cahiers Irice, No. 2, pp. 127-155, DOI: 10.3917/lci.oo2.0127.

Gerry, R., E. Lee, L. Swepston and J. Van Daele (2009) The Quest for SocialJustice, 1919-2009 (Geneva: ILO).

Ghebali, V.-Y. (1989) The International Labour Organization: a case study on the evolution of U.N. specialised agencies (Dordrecht: Martinus Nijhoff).

Guérin, D. (1996) Albert Thomas au BIT, 1920-1932: de l'internationalisme à l'Europe (Geneva: Institut européen de l'Université de Genève), p. 77.

Guinand, C. (2003) Die internationale Arbeitsorganisation (ILO) und die soziale Sicherheit in Europa (1942-1969) (Bern and New York: Lang), pp. 199-219.

Hensman, R. (2011) Workers, Unions, and Global Capitalism: Lessons from India (New York: Columbia University Press).

ILC (International Labour Conference) (1950) DG report (ILO), p. 3.

ILC (1944) Records of Proceedings, 26 (Montreal: ILO). 
ILC (1916) 'Resolutions of the International Labour Conference at Leeds, July 1916', in Shotwell, J. (ed.) (1934) The Origins of The International Labour Office, Documents, vol. 2 (New York: Columbia University Press), pp. 23-29.

International Labour Office (1931) Dix ans d'organisation internationale du travail (Geneva: International Labour Office).

ILO (International Labour Organization) (2018a) L'avenir du travail, http://www.ilo .org/global/topics/future-of-work/lang--fr/index.htm (accessed on 7 January 2018).

ILO (2018b) Normlex Information SystemonInternationalLabourStandards, http://www .ilo.org/dyn/normlex/fr/f?p=1000:1200o:6220762689995::::P1200o_INSTRUMENT_ SORT:4 (accessed on 08 January 2018).

ILO (1965) The effectiveness of ILO management development and productivity projects, Report and conclusions, management development series No. 3 (Geneva: ILO), p. 6.

ILO (1957a) 'Productivity missions to underdeveloped countries', International Labour Review, 76(1), pp. 2-29.

ILO (1957b) 'Productivity missions to underdeveloped countries', International Labour Review, $76(2)$.

ILO (1953) Committee of Experts on Social Policy in Non-Metropolitan Territories, Third Session, Lisbon, 7-19 December, p. 7.

ILO (1920) Procès Verbal du Conseil d'administration (PV CA), No. 3, pp. 41-52.

Kott, S. (2014) 'From transnational reformist network to International Organization: the International Association for Labour Legislation and the International Labour Organization (1900-1930)', in B. Struck, D. Rodogno and J. Vogel (eds.) Shaping the transnational Sphere (NYC: Berghahn Books), pp. 239-258.

Kott, S. (2012) 'The Forced Labour Issue between Human and Social Rights, 1947-1957', Humanity. An International Journal of Human Rights, Humanitarianism, and Development, 3(3), pp. 321-335, DOI: 10.1353/hum.2012.0025.

Kott, S. (2010) 'Constructing a European Social Model: The Fight for Social Insurance in the Interwar Period', in J. Van Daele, M. Rodriguez Garcia, G. van Goethem and M. van der Linden (eds.) ILO Histories: Essays on the International Labour Organization and its Impact on the World during the Twentieth Century (Bern and New York: Peter Lang), pp. 173-195.

Kott, S. (2008) 'Une “communauté épistémique” du social? Experts de l’OIT et internationalisation des politiques sociales dans l'entre-deux-guerres', Genèses, 71(2), pp. 26-46, DOI:10.3917/gen.071.0026.

Kott, S. and J. Droux (eds.) (2013) Globalizing Social Rights: The ILO and Beyond (London: Palgrave).

LN (League of Nations) (1920) International Labour Conference, First Annual Meeting, October 29, 1919 - November 29, 1919, Washington D.C., U.S.A. (Washington: Government Printing Office), p. 130. 
Lespinet-Moret, I. and V. Vincent (eds.) (2011) L'organisation internationale du travail: origine, développement, avenir (Rennes: Presses Universitaires de Rennes).

Louis, M. (2011) L'OIT et le travail décent. Un agenda social pour le multilatéralisme (Paris: L'Harmattan).

Maier, C.S. (2010) 'The World Economy and the Cold War in the Middle of the Twentieth Century', in M.P. Leffler and O.A. Westad (eds.) The Cambridge History of the Cold War, Origins, vol. 1 (Cambridge: Cambridge University Press), pp. 44-67.

Maier, C.S. (1977) 'The Politics of Productivity: Foundations of American International Economic Policy after World War II', International Organization, 31(4), October, pp. 607-633, DOI: 10.1017/Soo20818300018634.

Maul, D. (2012) Human Rights, Development, and Decolonization: the International Labour Organization, 1940-70 (New York: Palgrave Macmillan), pp. 31-40.

Maul, D. (2010) 'The Morse Years: The ILO 1948-1970', in J. Van Daele, M. Rodriguez Garcia, G. van Goethem and M. van der Linden (eds.) ILO Histories: Essays on the International Labour Organization and its Impact on the World during the Twentieth Century (Bern and New York: Peter Lang), pp. 365-400.

Maupain, F. (2010) 'Une Rolls Royce en mal de révision? L'efficacité du système de supervision de l'OIT à l'approche de son centenaire', Revue générale de droit international public, 114(3), pp. 465-499.

Moynihan, D.P. (1960) The United States and the International Labour Organization (1889-1934), unpublished thesis (Medford: Fletcher School of Law and Diplomacy).

Pasture, P. and S. Govaert (1999) Histoire du syndicalisme chrétien international: la difficile recherche d'une troisième voie (Paris and Montréal: Ed. L'Harmattan).

Phelan, E. (1949) 'L'OIT au service de la paix', Revue internationale du travail, 59(6), p. 664.

Polanyi, K. (1944) The Great Transformation (New York: Farrar and Rinehart), pp. 27-28. Reynaud, E. (2017) The International Labour Organization and the Living Wage: a Historical Perspective, Conditions of Work and Employment Series No. 90 (Geneva: ILO).

Riegelman, C. (1934) 'War-Time Trade-Union and Socialist Proposals', in J. Shotwell (ed.) The Origins of The International Labour Office, History, vol. 1 (New York: Columbia University Press), pp. 64-65.

Rodríguez-Piñero, L. (2005) Indigenous Peoples, Postcolonialism, and International Law: The ILO Regime, 1919-1989 (Oxford and New York: Oxford University Press), pp. $30-35$.

Shotwell, J. (ed.) (1934) The Origins of The International Labour Office, History, vol. 1, Documents, vol. 2 (New York: Columbia University Press).

Shotwell, J. (1933) 'The International Labour Organization as an Alternative to Violent Revolution', Annals of the American Academy of Political and Social Science, 166, pp.18-25, https://www.jstor.org/stable/1018783. 
Standing, G. (2008) 'The ILO: An Agency of Globalization?', Development and Change, 39(3), pp. 355-384, DOI: 10.1111/j.1467-7660.2008.00484.x.

Stenger, V. (2016) Une voie sociale pour le développement: Le Bureau international du travail et les débuts de la coopération technique (1919-1949) (Geneva: University of Geneva).

Tortora, M. (1980) Institution spécialisée et organisation mondiale: étude des relations de la OIT avec la SDN et l'ONU (Brussels: Émile Bruylant).

Tosstorff, R. (2005) 'The International Trade-Union Movement and the Founding of the International Labour Organization', International Review of Social History, 50(3), pp. 399-433, DOI: 10.1017/Soo20859005002166.

Van Daele, J. (2008) 'The International Labour Organization (ILO) in Past and Present Research', International Review of Social History, 53(3), pp. 485-511, DOI: 10.1017 / Soo20859008003568.

Van Daele, J. (2005) 'Engineering Social Peace: Networks, Ideas, and the Founding of the International Labour Organization', International Review of Social History, 50(3), pp. $435^{-466 .}$

Van Daele, J., M. Rodriguez Garcia, G. van Goethem and M. van der Linden (eds.) (2010) ILO Histories: Essays on the International Labour Organization and its Impact on the World during the Twentieth Century (Bern and New York: Peter Lang).

Zimmermann, S. (2010) "Special Circumstances in Geneva": The ILO and the World of Non-Metropolitan Labour in the Interwar Period', in J. Van Daele, M. Rodriguez Garcia, G. van Goethem and M. van der Linden (eds.) ILO Histories: Essays on the International Labour Organization and its Impact on the World during the Twentieth Century (Bern and New York: Peter Lang), pp. 221-250. 